\title{
ANALISIS JALUR PENGARUH TEKNIK HITUNG VEDIC MATH, SUKU MAYA, DAN CHUNKING TERHADAP PERHITUNGAN AKAR KUADRAT METODE BABILONIA
}

\author{
Endro Tri Susdarwono \\ Universitas Peradaban, Indonesia \\ midas999saniscara@gmail.com
}

\begin{abstract}
:
The purpose of this research was to discuss how the influence of several calculation techniques that exist both in the west and in the east, especially the Vedic Math, Maya, Chunking and Square Root Babylonian methods based on the use of path analysis. The approach in this research used a descriptive approach, the method used was quantitative methods. The quantitative approach used statistical tests with path analysis to answer the relationship and influence between the 4 variables. From the results of the path analysis, it found that there was an effect of X1 (mastery of addition and subtraction with Vedic Math), X2 (mastery of multiplication by the Mayan tribe), X3 (mastery of division using the Chunking Method) on X3 (mastery of calculating square roots with Babylonian Middle Iteration). The total effect was 0.887 , The total effect of 0.887 shows that the influence of Vedic Math's control of addition and control, mastery of the multiplication of the Maya method, and mastery of the division of the Chunking method based on path analysis had a joint effect on students' ability to calculate questions related to the square root of the Babylonian middle iteration technique.
\end{abstract}

Keywords: chunking, multiplication of the Maya tribe, path analysis, square root, Babylonian method, Vedic math.

\section{PENDAHULUAN}

Matematika merupakan pelajaran yang diajarkan disetiap level sekolah, dari Sekolah Dasar hingga Universitas (Vilianti, Pratama, \& Mampouw, 2018). Manthanein atau mathema adalah akar kata matematika yang berasal dari bahasa latin yang bermakna belajar atau hal yang dipelajari, sedangkan kata lain dari bahasa Belanda yaitu wiskunde yang bermakna ilmu pasti (Siagian, 2017). Matematika didefinisikan oleh para ahli pendidikan matematika sebagai ilmu yang membahas pola atau keteraturan (pattern) dan tingkatan. Konsep tertentu dalam matematika membutuhkan benda-benda konkret atau manipulatif jika kita berkeinginan memberikan pemahaman yang utuh bagi siswa. Dengan bantuan benda konkret diharapkan dapat membantu pemahaman siswa sehingga diharapkan bertahan lama dalam ingatan mereka (Lado, Muhsetyo, \& Sisworo, 2016).

Beberapa penelitian menyatakan bahwa salah satu penyebab kegagalan dalam pembelajaran matematika adalah siswa tidak paham konsep-konsep matematika atau siswa salah dalam memahami konsep-konsep matematika (Novitasari, 2016). Matematika adalah mata pelajaran yang terkenal "sulit", bahkan menjadi momok bagi banyak anak. Pada sisi lain ternyata ada juga anak 
yang menganggap matematika itu menyenangkan bahkan menantang. Perbedaan persepsi ini selain dilihat sebagai semata-mata karena perbedaan selera masingmasing manusia, mungkin juga terkait dengan pengalaman buruk atau pengalaman menarik anak tersebut saat berinteraksi dengan matematika (Arryawan, 2011). Perilaku tersebut juga disebabkan pengalaman siswa dalam mempersepsikan matematika dan guru matematika (Pardimin \& Widodo, 2016). Relevansi terhadap kegunaan dan kepentingan siswa dalam kehidupannya diperlukan dalam pembelajaran matematika dan tidak sekedar menyusun urutan informasi (Fuadi, Johar, \& Munzir, 2016).

Menurut Gazali (2016) mengatakan bahwa obyek dalam matematika diklasifikasikan atas fakta, keterampilan, konsep, dan prinsip. Fakta merupakan suatu konvensi atau kesepakatan dalam matematika, misalnya simbol-simbol dalam matematika. Sedangkan keterampilan (skill) matematika merupakan gabungan antara operasi dan prosedur di mana matematikawan diharapkan dapat menyelesaikan persoalan dengan cepat dan tepat. Konsep merupakan suatu ide atau gagasan abstrak yang memungkinkan seseorang dapat mengklasifikasikan obyek-obyek atau peristiwa-peristiwa tertentu dan memungkinkan pula untuk menentukan apakah obyek-obyek atau peristiwa-peristiwa tertentu itu merupakan contoh atau bukan contoh dari gagasan tersebut. Prinsip adalah obyek matematika yang lebih kompleks.

Prinsip dapat terdiri atas beberapa konsep yang dikaitkan oleh suatu relasi/operasi, dengan kata lain prinsip adalah hubungan antara berbagai objek dasar matematika. Prinsip dapat berupa aksioma, teorema dan sifat. Operasi, merupakan pengerjaan hitung, pengerjaan aljabar, dan pengerjaan matematika lainnya, seperti penjumlahan, perkalian, gabungan, irisan (Hasratuddin, 2018). Konsep-konsep dalam matematika yang abstrak tersusun berjenjang dan berurutan masih diperlukan pembuktian-pembuktian khusus, sehingga dalam mempelajari matematika konsep sebelumnya harus dikuasai karena merupakan prasyarat untuk melanjutkan konsep berikutnya (Graciella \& Suwangsih, 2016).

Tujuan yang lebih komprehensif dalam pembelajaran matematika sesuai dengan tuntutan kurikulum yaitu: (1) memahami konsep matematika, yaitu menjelaskan keterkaitan antarkonsep dan mengaplikasikan konsep atau algoritma, secara luwes, akurat, efisien, dan tepat, dalam pemecahan masalah; (2) menggunakan penalaran pada pola dan sifat, melakukan manipulasi matematika dalam membuat generalisasi, menyusun bukti, atau menjelaskan gagasan dan pernyataan matematika; (3) memecahkan masalah yang meliputi kemampuan memahami masalah, merancang model matematika, menyelesaikan model dan menafsirkan solusi yang diperoleh; (4) mengomunikasikan gagasan dengan simbol, tabel, diagram, atau media lain untuk memperjelas keadaan atau masalah; dan (5) memiliki sikap menghargai kegunaan matematika dalam kehidupan, yaitu memiliki rasa ingin tahu, perhatian, dan minat dalam mempelajari matematika, serta sikap ulet dan percaya diri dalam pemecahan masalah (Kamarullah, 2017). Namun demikian siswa pembelajar matematika seringkali mengalami kesulitan dalam kegiatan pembelajarannya diantaranya adalah kesulitan menghitung cepat, dan kemampuan berlogika (Amir, 2016).

Kecintaan anak terhadap matematika bisa dibangun lewat beberapa jalan. Pertama: melalui visualisasi dan peragaan. Dengan peragaan atau bahkan

Alifmatika: Jurnal Pendidikan dan Pembelajaran Matematika, Desember 2020, Vol. 2, No. 2 
permainan, anak bisa melihat, merasakan suatu proses. Alat peraga matematika bisa benda apa saja yang sederhana, misalnya saja kelereng, koin logam, dan sebagainya. Kedua: melalui eksplorasi atau penjelajahan. Anak terlibat merasakan suatu proses, anak berada di dalam proses itu, tidak semata-mata menghafalkan rumus. Ketiga: dengan membangkitkan harga diri anak. Anak yang menguasai trik tertentu misalnya saja trik cara menghitung mudah, pandai dalam teka teki matematika atau pandai sulap matematika akan terkesan keren di mata temantemannya. Ini menciptakan efek berantai, anak tersebut menjadi suka dan ingin belajar matematika lebih dalam lagi (Nasaruddin, 2015).

Penelitian Diputra \& Sudiarta (2018) menyimpulkan bahwa Model penyelesaian Matematika Veda (Vedic math) dengan penalaran rasional dan logis melatih siswa untuk dapat meningkatkan keterampilan, ketepatan dan kemudahan berhitung. Peradaban terkenal suku Maya juga mewariskan bagaimana metode atau teknik mudah dalam perkalian yang bahkan untuk anak Sekolah Dasar yang tidak hafal dengan nilai perkalian dapat menggunakannya (Blume, 2011). TheSchoolRun (2020) menyimpulkan bahwa tujuan metode chungking it adalah agar anak-anak dapat memikirkan hubungan antara perkalian dan pembagian. Ini melibatkan penggunaan perkiraan kasar berapa kali sebuah angka akan berubah menjadi angka lain dan kemudian menyesuaikan hingga jawaban yang benar ditemukan. Setelah keterampilan ini sering dipraktikkan siswa, maka akan mempercepat siswa dalam melakukan pembagian.

Terkait dengan menghitung akar kuadrat dengan iterasi tengah Babilonia, iterasi adalah proses perhitungan sederhana berulang-ulang yang biasanya dipakai untuk program komputer (Thiemann, 2013). Ada banyak iterasi yang mungkin untuk menghitung akar kuadrat misalnya iterasi interval tengah, iterasi interpolasi linier dan sebagainya. Apabila nilai awal yang diambil cukup dekat, iterasi Babilonia biasanya hanya butuh satu atau dua langkah saja untuk mendapatkan akar yang cukup dekat dengan akar sebenarnya (Fowler \& Robson, 1998).

Dunia Matematika sebenarnya begitu luas. Bahkan teknik ilmu hitung dasar semacam KaBaTaKur (Kali Bagi Tambah Kurang) sebenarnya banyak macamnya. Sekolah biasanya hanya mengambil satu cara dan mengabaikan cara yang lain (Arryawan, 2011). Cara yang tidak diajarkan di sekolah tidak selalu buruk. Sebagian di antaranya justru lebih mudah dan/atau lebih cepat sehingga justru membantu anak dalam menguasai matematika.

Berdasarkan latar belakang diatas penelitian ini bertujuan untuk melihat pengaruh beberapa teknik hitung yang ada baik di barat maupun di timur utamanya adalah teknik hitung Vedic Math, Suku Maya, Chunking serta Akar Kuadrat Metode Babilonia berdasarkan penggunaan analisis jalur (path analysis). Penelitian dilakukan didasarkan pada kemudahan atau kecepatan terhadap metode atau teknik yang dimaksud, dan diasumsikan bahwa teknik hitung Vedic math, suku maya, chunking berpengaruh secara bersama-sama terhadap kemampuan siswa menyelesaikan soal akar kudrat menggunakan metode akar kuadrat Babilonia.

Alifmatika: Jurnal Pendidikan dan Pembelajaran Matematika, Desember 2020, Vol. 2, No. 2 


\section{METODE PENELITIAN}

Metode yang digunakan dalam penelitian ini adalah eksperimen. Menurut Sugiyono (2017) mengatakan bahwa metode eksperimen adalah suatu metode penelitian yang berusaha mencari hubungan variabel tertentu terhadap variabel lain dalam kondisi yang terkontrol secara ketat. Sementara itu, Suharsimi (2006) mengemukakan bahwa metode eksperimen adalah suatu cara untuk mencari hubungan sebab akibat (hubungan kausal) antara dua faktor yang sengaja ditimbulkan oleh peneliti dengan mengeliminasi atau mengurangi atau menyisihkan faktor-faktor lain yang mengganggu.

Secara umum, karakteristik penelitian eksperimen dalam penelitian ini meliputi: (1) Peneliti memanipulasi variabel bebas dengan memberikan perlakuan pemberian pembelajaran matematika melalui metode/teknik hitung Vedic Math, Suku Maya, Chunking serta Akar Kuadrat Metode Babilonia . Perlakuan tersebut bertujuan agar apa yang diharapkan peneliti dalam penelitian dapat tercapai. Variabel bebas yang dimanipulasi dalam penelitian ini adalah model/metode pembelajaran yakni menggunakan pembelajaran matematika; (2) Pengendalian atau kontrol dilakukan dengan menambahkan faktor lain yang diinginkan peneliti dari variabel yang diteliti; (3) Setelah perlakuan diberikan selama kurun waktu tertentu, peneliti melakukan pengamatan atau pengukuran untuk mengetahui pengaruh dari manipulasi/perlakuan yang diberikan terhadap variabel yang diteliti. Pengamatan dilakukan melalui pengumpulan data berupa tes.

\section{Desain Penelitian}

Desain kuantitatif yang akan digunakan dalam penelitian ini berupa desain penelitian eksperimen The One-Shot Case Study Design. Desain ini digunakan karena dalam penelitian ini terdapat suatu kelompok yang diberi perlakuan (treatment), dan selanjutnya diobservasi hasilnya. Perlakuan (treatment) sebagai variabel independen dan hasil yang diobervasi sebagai variabel dependen. Teknik sampling yang digunakan untuk desain ini adalah purposive sampling.
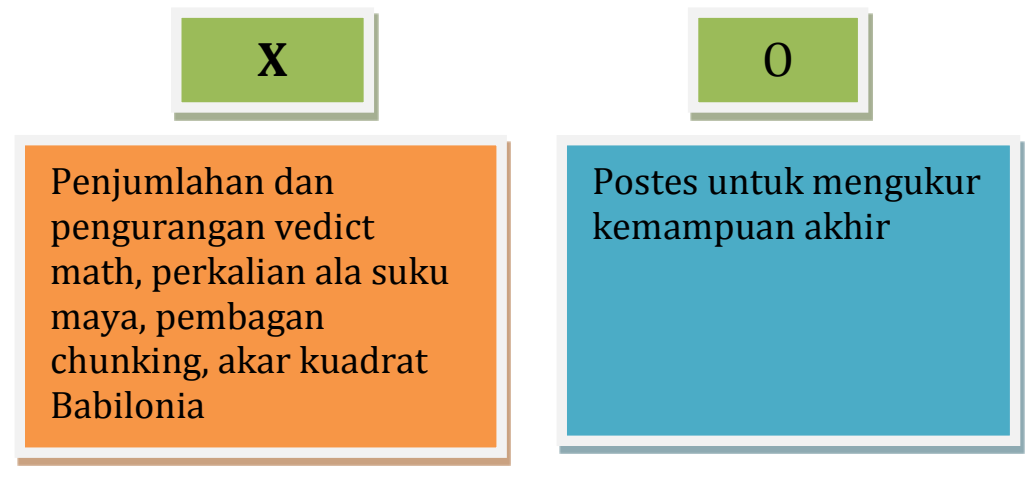

Gambar 1. The One-Shot Case Study Design

Keterangan:

$\mathrm{X}=$ perlakuan/treatment yang diberikan (variabel independen)

$0=$ postes (variabel dependen yang diobservasi)

Alifmatika: Jurnal Pendidikan dan Pembelajaran Matematika, Desember 2020, Vol. 2, No. 2 


\section{Endro Tri Susdarwono}

\section{Teknik Analisis Data}

Penulis melakukan analisis data dengan menggunakan Analisis Jalur (Path Analysis) untuk menguji pengaruh variabel intervening. Analisis jalur merupakan perluasan dari analisis regresi linear berganda, atau analisis jalur adalah penggunaan analisis regresi untuk menaksir hubungan kausalitas antar variabel (model casual) yang telah ditetapkan sebelumnya berdasarkan teori. Analisis jalur sendiri tidak dapat menentukan hubungan sebab akibat dan juga tidak dapat digunakan sebagai substitusi bagi peneliti untuk melihat hubungan kausalitas antar variabel. Hubungan kausalitas antar variabel telah dibentuk dengan model berdasarkan landasan teoretis. Apa yang dilakukan oleh analisis jalur adalah menentukan pola hubungan antara tiga atau lebih variabel dan tidak dapat digunakan untuk mengkonfirmasi atau menolak hipotesis kasualitas imajiner. Berikut model analisis jalur (analisis jalur yang diuji dalam penelitian ini.

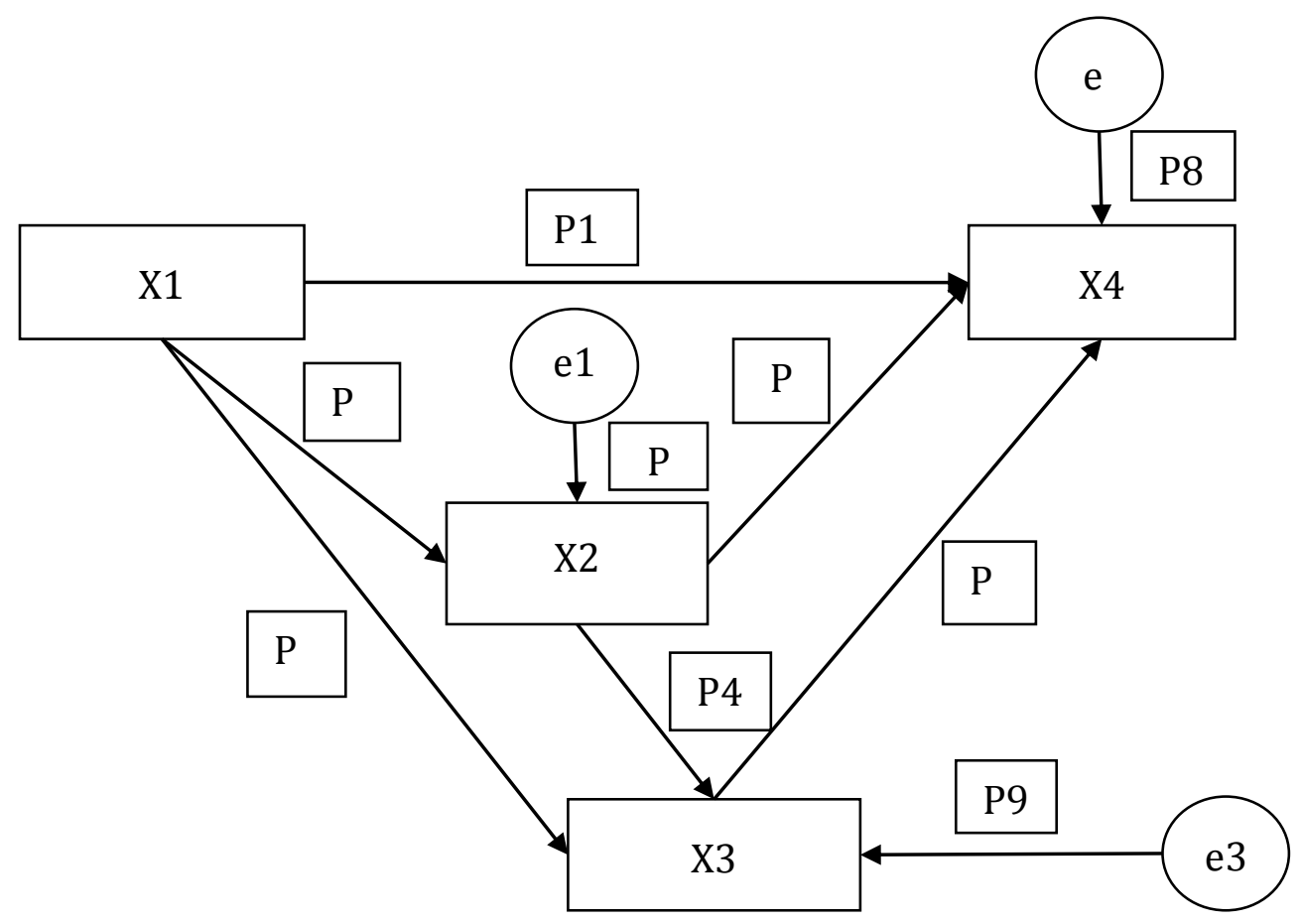

Gambar 2. Model Analisis Jalur (Path Analysis)

Ada empat variabel yang ingin dilihat yaitu X1 (penguasaan penjumlahan dan pengurangan dengan Vedic Math), X2 (penguasaan perkalian ala Suku Maya), X3 (penguasaan pembagian dengan Metode Chunking), dan X3 (penguasaan menghitung akar kuadrat dengan Iterasi Tengah Babilonia). Secara teori hubungan antar variabel dapat dilihat seperti dalam gambar di atas. Dalam model ini diajukan hipotesis bahwa X1 berpengaruh langsung terhadap X4 p1, namun demikian juga dihipotesiskan bahwa X1 mempunyai pengaruh tidak langsung terhadap X4 dengan hubungan tidak langsung sebagai berikut:

- $\quad$ X1 mempengaruhi X3 (p5), kemudian mempengaruhi X4 (p6)

- $\quad$ X1 mempengaruhi X2 (p2), kemudian X3 mempengaruhi X4 (p3)

Alifmatika: Jurnal Pendidikan dan Pembelajaran Matematika, Desember 2020, Vol. 2, No. 2 
- X1 mempengaruhi X2 (p2), kemudian mempengaruhi X3 (p4) dan kemudian mempengaruhi X4 (p6)

\section{HASIL DAN PEMBAHASAN}

Berikut adalah manipulasi/perlakuan yang diberikan terhadap variabel yang diteliti berupa kemampuan teknik hitung yang diberikan dalam pembelajaran matematika untuk siswa Sekolah Dasar (SD) untuk selanjutnya diambil nilai postest. Berdasarkan nilai postes tersebut dilakukan analisis jalur analis jalur.

1. Penjumlahan Mudah dengan Vedic Math

Vedic Math adalah teknik hitung praktis yang diturunkan dari ilmu hitung India Kuno. Penjumlahan ala Vedic Math yang dipaparkan merupakan penjumlahan dari kiri ke kanan yang merupakan penyederhanaan dari bentuk Tangga Kebijaksanaan.

Berikut soal yang diberikan ke siswa dan contoh jawaban. Dengan penjumlahan ala Vedic Math hitunglah.

1) $1235+8978=?$

2) $567+869=?$

3) $45678+78967=?$

4) $2356+3456=$ ?

5) $721+943=?$

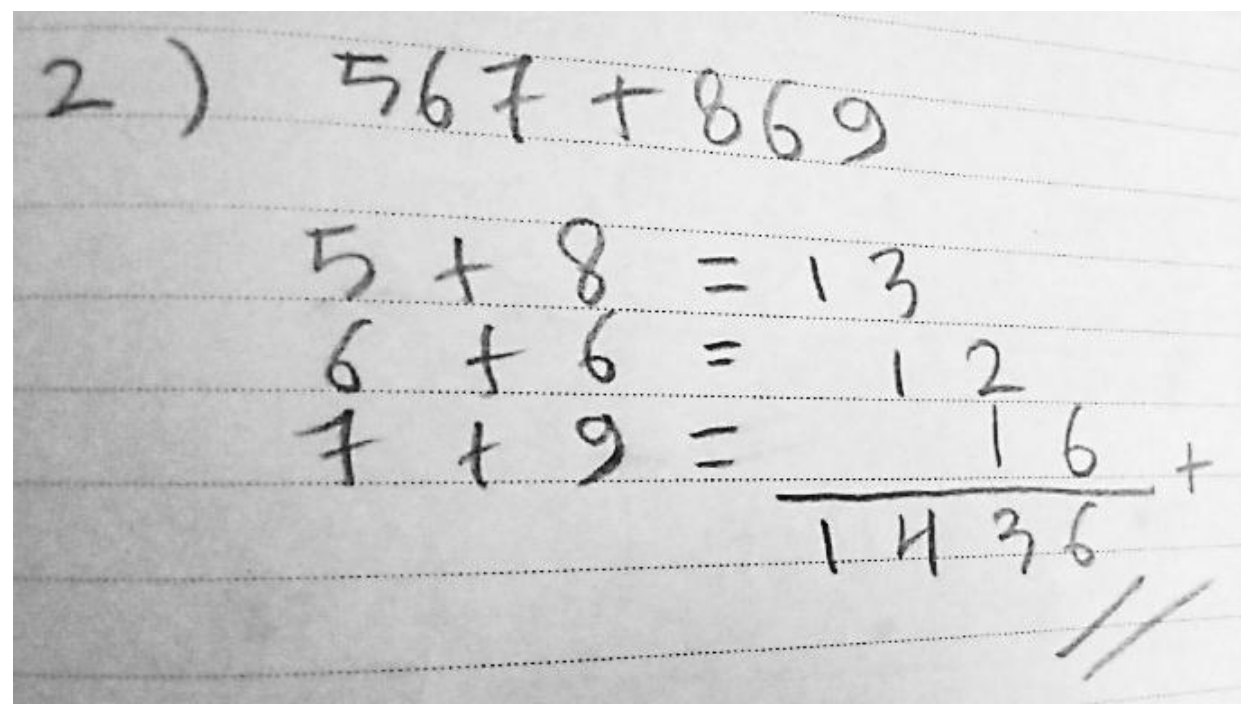

Gambar 3. Contoh jawaban Siswa Perhitungan Memakai Vedic Math

2. Pengurangan Mudah dengan Teknik Sembilan sepuluh Vedic Math

Teknik yang ditulis ini berasal dari ide Vedic Math, yang diturunkan dari ilmu hitung India kuno. Ada sedikit modifikasi karena pada Vedic Math, umumnya teknik ini dipakai untuk menghitung pengurangannya dengan angka belakang nol nol nol. Pada jurus yang sudah dimodifikasi semua bilangan bisa dihitung dengan memakai cara ini.

Berikut soal yang diberikan ke siswa dan contoh jawaban. Dengan pengurangan 9910 ala Vedic Math, hitunglah.

Alifmatika: Jurnal Pendidikan dan Pembelajaran Matematika, Desember 2020, Vol. 2, No. 2 
1) $300157-7889=?$

2) $612-198=$ ?

3) $28523788-26716899=$ ?

4) $123423-7689=$ ?

5) $782222-29898=?$

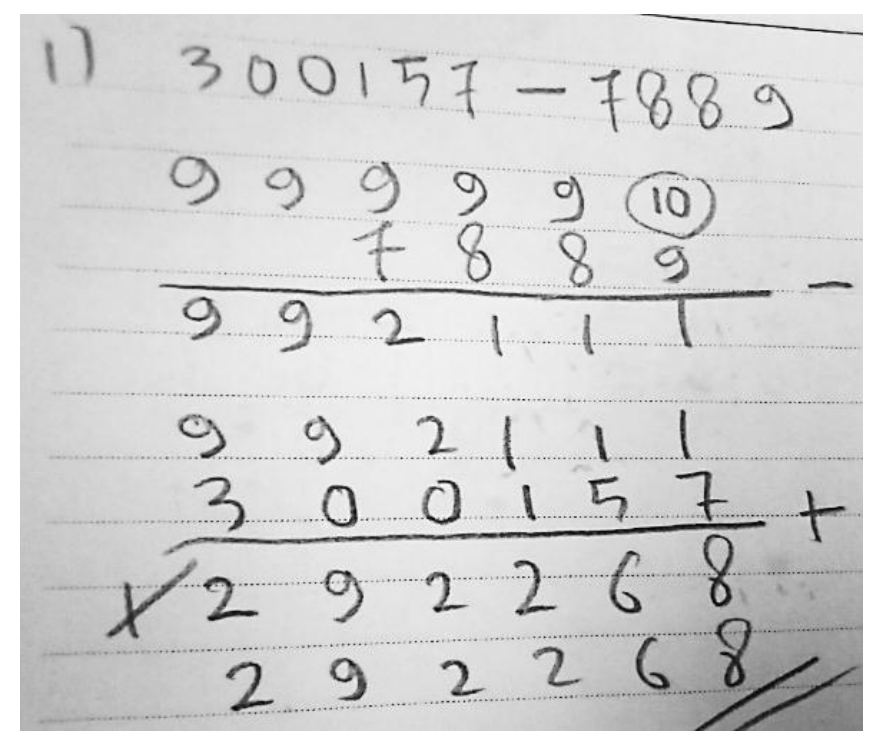

Gambar 4. Contoh Jawaban Siswa Pengurangan Mudah Teknik Sembilan Sepuluh Vedic Math

3. Perkalian Mudah ala Suku Maya

Suku Maya sempat menjadi demikian terkenal akhir-akhir ini karena sering dikaitkan dengan isu kiamat 2012 yang konon berdasarkan ramalan canggih dari tokoh Suku Maya. Masalah kiamat tentu hanya Tuhan yang tahu. Serta sebenarnya suku Maya sendiri menolak dikaitkan dengan isu-isu mengenai hari kiamat pada tanggal tertentu. Jadi maslah kiamat yang dihubungkan dengan Suku Maya hanyalah sekadar isu belaka. Tetapi terlepas dari isu tersebut, suku Maya memang terkenal sebaga suku yang memiliki kemampuan hitung tinggi.

Teknik perkalian mudah kali ini diadaptasi dari ilmu hitung ala Suku Maya. Teknik ini sudah dicoba oleh siswa SD yang sebelumnya mengalami kesulitan menghadapi soal-soal perkalian. Sorang anak yang sebelumnya mengalami kesulitan menghitung perkalian tampak langsung Bahagia bahkan dalam pandangan pertama ketika diajarkan teknik ini.

Berikut soal yang diberikan ke siswa dan contoh jawaban. Dengan teknik menggambar garis dan menghitung titik ala suku Maya, hitunglah.
1) $54 \times 58=$ ?
2) $203 \times 5=$ ?
3) $458 \times 785=$ ?
4) $23 \times 456=$ ?
5) $23 \times 34=$ ?

Alifmatika: Jurnal Pendidikan dan Pembelajaran Matematika, Desember 2020, Vol. 2, No. 2 


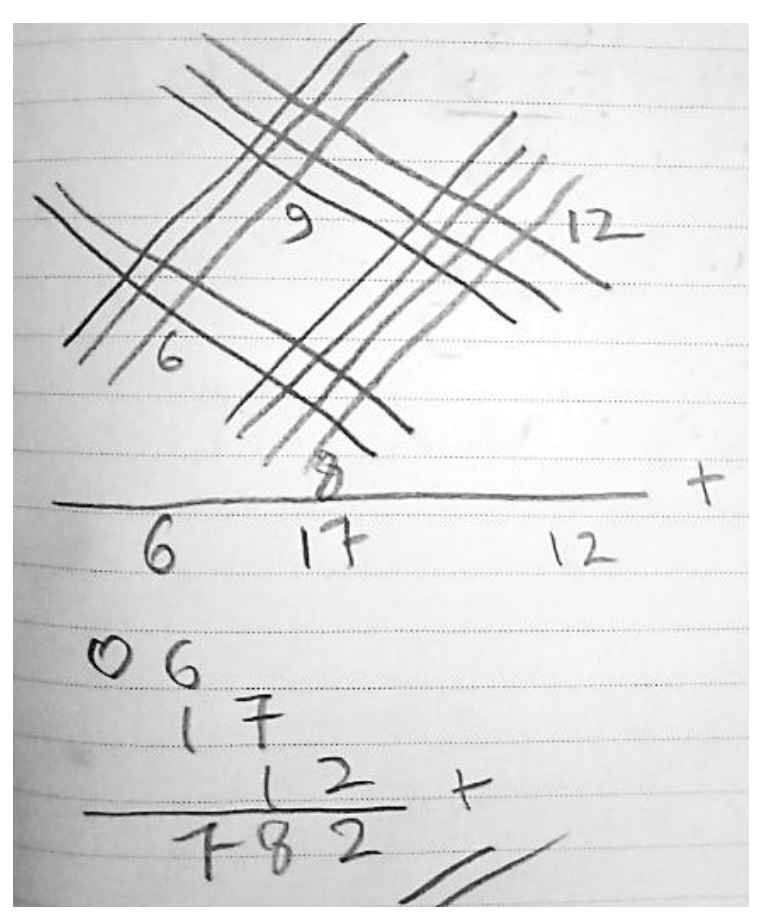

Gambar 5. Contoh Jawaban Siswa Teknik Perkalian Ala Suku Maya

4. Pembagian mudah dengan Metode Chunking (Chunk It)

Perkalian memiliki sifat distributif atau penyebaran. Misalnya saja. Perkalian $12 \times 14=(10 \times 14)+(2 \times 14)$ atau $(5 \times 14)+(5 \times 14)+(2 \times 14)$ atau persamaan lain sembarang asalkan apabila dijumlahkan hasilnya 12 .

$12 \times 14=(10+2) \times 14=(10 \times 14)+(2 \times 14)$

$12 \times 14=(5+5+2) \times 14=5 \times 14+5 \times 14+2 \times 14$

Sifat ini bisa dipakai untuk menghitung pembagian mudah dengan metode Chunking. Ini adalah salah satu teknik pembagian mudah yang diajarkan di Barat. Metode ini dikenal karena kemudahan dan kebebasannya. Berikut soal yang diberikan ke siswa dan contoh jawaban. Dengan teknik Chunk it hitunglah pembagian berikut ini.
1) $1880: 19 \times 58=$ ?
2) $3456: 23$ ?
3) $168: 12=$ ?
4) $1884: 12=$ ?
5) $1780: 12=?$

Alifmatika: Jurnal Pendidikan dan Pembelajaran Matematika, Desember 2020, Vol. 2, No. 2 


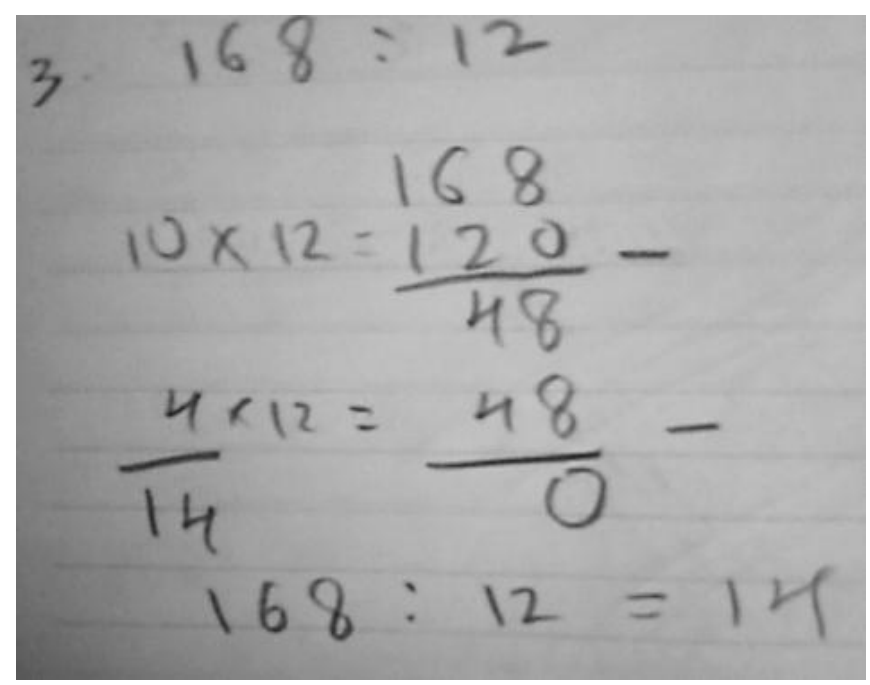

Gambar 6. Contoh Jawaban Siswa Teknik Pembagian Metode Chunking

5. Menghitung Akar Kuadrat dengan Iterasi Tengah Babilonia

Pada pembahasan sebelumnya kita sudah pernah membahas ailmu hitung yang berasal dari Suku Maya Indian Amerika serta Vedic Math India yang diturunkan dari weda. Pada pembahasan kali ini kita akan mempelajari jurus hitung lain yang diturunkan dari Metode Ilmu Hitung Babilonia. Langkah-langkah mencari akar kuadarat ala Bangsa Babilonia. Anggap saja kita ingin menghitung akar kuadrat dari A.

a. Pertama: menentukan nilai akar dari A. anggap saja kita namakan itu x. kita bisa memilih x sembarang angka sebagai akar A, tetapi jika perkiraan awal ini "tidak terlalu ngawur" maka proses perhitungannya akan lebih cepat. Misalnya jika kita ingin menghitung berapa akar kuadrat dari 500? Tidak masalah jika Anda mengisikan misalnya harga awal 40, tetapi akan lebih cepat perhitungannya jika anda isikan misalnya 20, karena $20 \times 20=400$ cukup dekat dengan 500. Atau akan lebih cepat lagi perhitungannya jika anda isikan 22, karena 22 kali $22=484$ lebih dekat ke 500 .

b. Kedua: hitung nilai dari A dibagi angka tebakan atau A dibagi x. bila kita menghitung akar 500, dan memberi nilai $\mathrm{x}=20$ maka berarti kita harus menghitung 500/20. Anggap saja kita namakan itu $y$.

c. Ketiga: hitung nilai tengah atau rata-rata dari $\mathrm{x}$ dan $\mathrm{y}$. akar kuadrat dari $\mathrm{A}$ adalah pendekatan dari Nilai Tengah tersebut.

Berikut soal yang diberikan ke siswa dan contoh jawaban. Dengan teknik menggambar garis dan menghitung titik ala suku Maya, hitunglah.
1) $\sqrt{20}=$ ?
2) $\sqrt{500}=?$
3) $\sqrt{230}=$ ?
4) $\sqrt{1000}=$ ?
5) $\sqrt{650}=$ ?

Alifmatika: Jurnal Pendidikan dan Pembelajaran Matematika, Desember 2020, Vol. 2, No. 2 


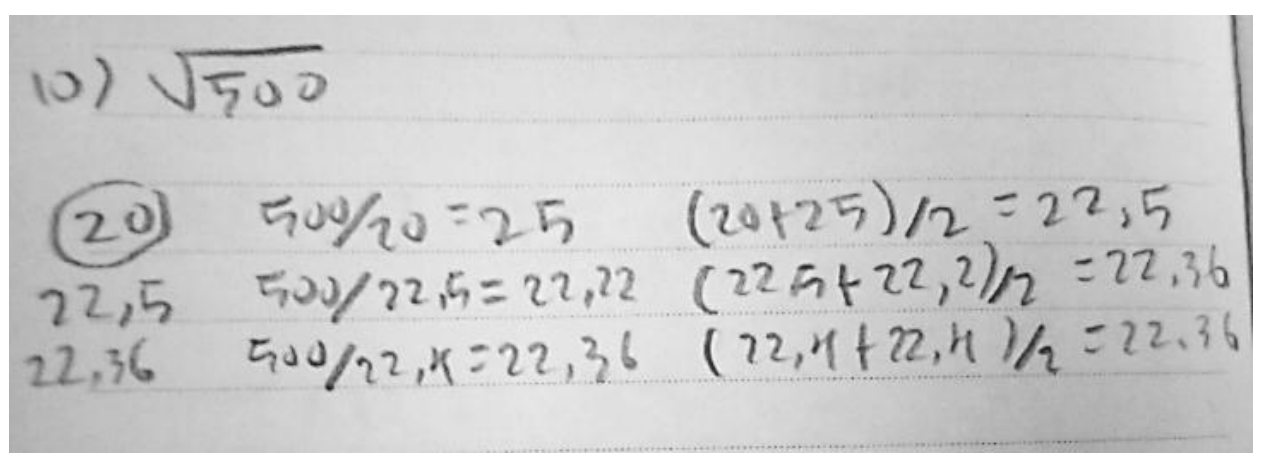

Gambar 7. Contoh Jawaban Siswa Menghitung Akar Kuadrat dengan Iterasi Tengah Babilonia

Setelah perlakuan diberikan kemudian dilakukan postest berupa soal dengan masing-masing berjumlah 5 soal terhadap siswa sehingga didapatkan nilai seperti tabel berikut.

Tabel 1. Nilai Postest Terhadap 8 Siswa

\begin{tabular}{ccccc}
\hline & X1 & X2 & X3 & X4 \\
\hline Mean & 64,875 & 73,625 & 76,875 & 79 \\
Min & 56 & 62 & 64 & 68 \\
Max & 72 & 85 & 88 & 90 \\
Varian & 21,268 & 53,696 & 78,982 & 72 \\
Std. Dev & 4,612 & 7,328 & 8,887 & 8,485 \\
\hline
\end{tabular}

Adapun untuk menganalisis hubungan antar variabel dalam penelitian ini diperlukan tiga persamaan regresi sebagai berikut.

1) $\mathrm{X} 2=\mathrm{b} 1 \mathrm{X} 1+\mathrm{e} 1$

2) $\mathrm{X} 4=\mathrm{b} 1 \mathrm{X} 1+\mathrm{b} 2 \mathrm{X} 2+\mathrm{b} 3 \mathrm{X} 3+\mathrm{e} 2$

3) $\mathrm{X} 3=\mathrm{b} 1 \mathrm{X} 1+\mathrm{b} 2 \mathrm{X} 2+\mathrm{e} 3$

Nilai koefisien standardized X1 pada persamaan (1) memberikan nilai p2. Sedangkan koefisien standardized untuk variabel X1, X2, dan X3 pada persamaan (2) memberikan nilai p1, p3, dan p6. Nilai koefisien X1 dan X2 pada persamaan (3) memberikan nilai p5 dan p4. Pada Tabel berikut ditampilkan regresi untuk persamaan (1), (2), dan (3).

Tabel 2. Tabel kerja untuk Regresi Persamaan (1)

\begin{tabular}{ccccc}
\hline Model & R Square & Beta & T & Sig. \\
\hline X1 & 0,926 & 0,962 & 8,660 & 0,00 \\
\hline
\end{tabular}


Tabel 3. Tabel kerja untuk Regresi Persamaan (2)

\begin{tabular}{ccccc}
\hline Model & R Square & Beta & T & Sig. \\
\hline X1 & 0,999 & $-0,375$ & $-5,998$ & 0,004 \\
X2 & & 0,537 & 5,213 & 0,006 \\
X3 & & 0,817 & 11,902 & 0,000 \\
\hline
\end{tabular}

Tabel 4. Tabel kerja untuk Regresi Persamaan (3)

\begin{tabular}{ccccc}
\hline Model & R Square & Beta & T & Sig. \\
\hline X1 & 0,944 & $-0,262$ & $-0,671$ & 0,532 \\
X2 & & 1,221 & 3,128 & 0,026 \\
\hline
\end{tabular}

Dari hasil output SPSS didapat persamaan regresi berikut.
1) $X 2=0,962 X 1$
$\mathrm{R}^{2}=0,926$
2) $X 4=-0,375 X 1+0,537 X 2+0,817 X 3$
$\mathrm{R}^{2}=0,999$
3) $\mathrm{X} 3=-0,262 \mathrm{X} 1+1,221 \mathrm{X} 2$
$\mathrm{R}^{2}=0,944$

$$
\begin{aligned}
& e 1=\sqrt{(1-0,926)}=0,272 \\
& e 2=\sqrt{(1-0,999)}=0,032 \\
& e 1=\sqrt{(1-0,44)}=0,237
\end{aligned}
$$

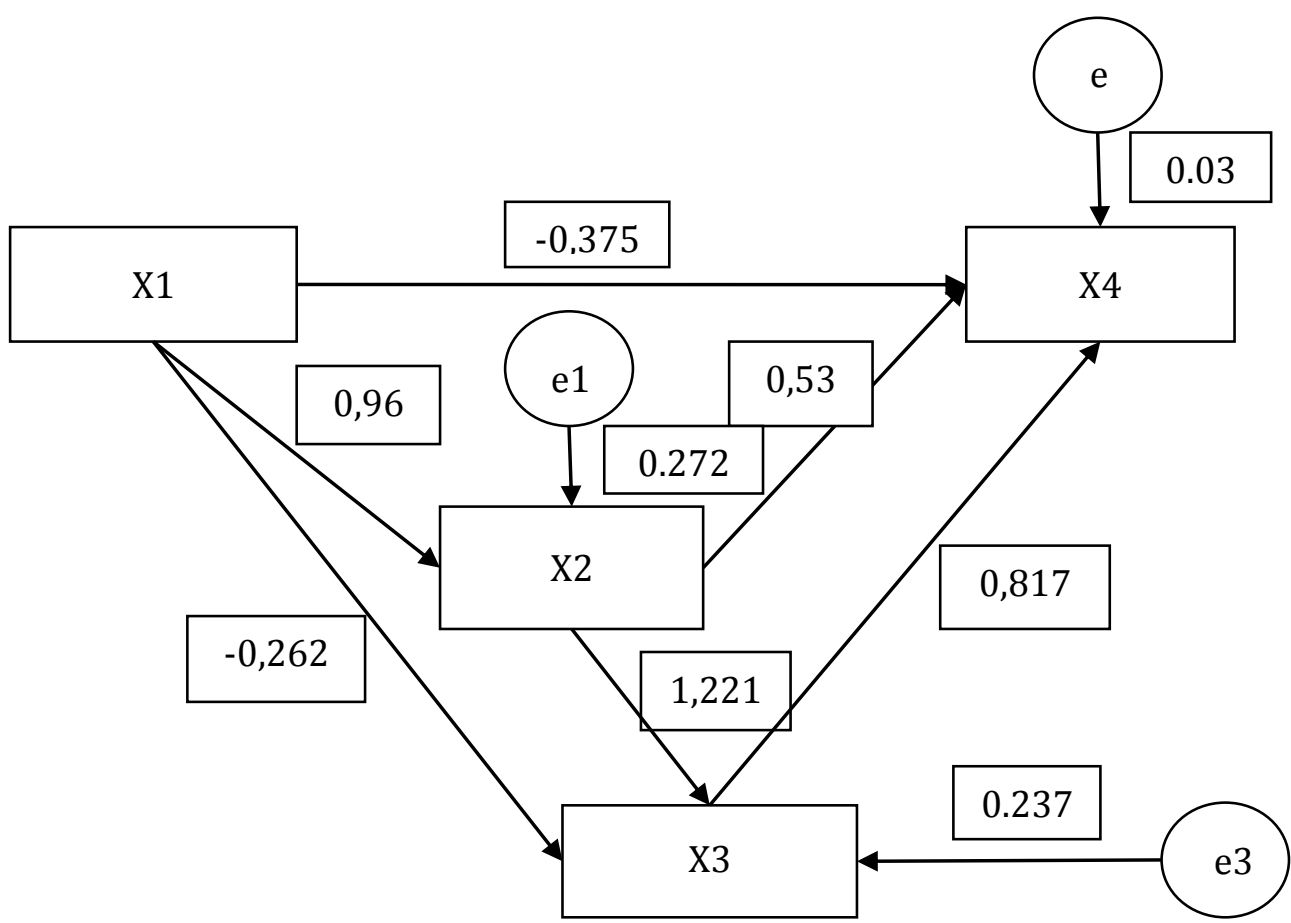

Gambar 8. Hasil PerhitunganModel Analisis Jalur (Path Analysis) 
Interpretasi dari hasil analisis jalur dapat dilakukan sebagai berikut. Total pengaruh X1 terhadap X4 dapat dilihat sebagai berikut. Pengaruh langsung X1 ke $\mathrm{X} 4=-0,375$

Pengaruh tidak langsung:

- $\quad \mathrm{X} 1$ ke X2 ke X4 = 0,962 ×0,537 =0,517

- $\mathrm{X} 1$ ke X2 ke X3 ke X4 =0,962 ×1,221 ×0,817 =0,960

- $\mathrm{X} 1$ ke X3 ke X4 = -0,262 ×0,817 = -0,214

Total pengaruh $\mathrm{X} 1$ ke $\mathrm{X} 4=0,887$, terkait dengan penelitian ini maka total pengaruh sebesar 0,887 menunjukkan bahwa pengaruh penguasaan penjumlahan dan pengurangan Vedic Math, penguasaan perkalian metode Suku Maya, dan penguasaan pembagian metode Chunking siswa berdasarkan analisis jalur memberikan pengaruh secara bersama sama terhadap kemampuan siswa dalam menghitung soal yang terkait dengan akar kuadrat teknik iterasi tengah Babilonia. Hasil penelitian ini sejalan dengan hasil penelitian yang didapat oleh Gaskell, (Helma, 2011) menunjukkan bahwa penerapan Vedic Mathematics di sekolah Maharishi di Lanchasire Inggris, diketahui bahwa pembelajaran matematika berlangsung lebih hidup dan menyenangkan. Siswa-siswa mengerjakan tugas dengan lebih bersemangat. Temuan ini jauh lebih baik dari apa yang diharapkan sebelum penelitian. Tetapi, keefektifan dari Vedic Mathematics tidak dapat diapresiasikan secara menyeluruh tanpa latihan secara nyata. Hasil penelitian ini juga sejalan dengan hasil penelitian yang didapat oleh Anggraini, (2016) menunjukkan bahwa metode chunking efektif untuk meningkatkan pemahaman membaca siswa. Penelitian ini berhasil menyelesaikan masalah siswa dalam memahami teks dengan menggunakan metode chunking.

\section{KESIMPULAN DAN SARAN}

Berdasarkan hasil teknik analisa statistik melalui pengujian analisis jalur (path analysis) terhadap hasil postest maka disimpulkan bahwa terdapat pengaruh X1 (penguasaan penjumlahan dan pengurangan dengan Vedic Math), X2 (penguasaan perkalian ala Suku Maya), X3 (penguasaan pembagian dengan Metode Chunking) terhadap X3 (penguasaan menghitung akar kuadrat dengan Iterasi Tengah Babilonia). Total pengaruh sebesar 0,887. 


\section{DAFTAR PUSTAKA}

Amir, A. (2016). Penggunaan Media Gambar dalam Pembelajaran Matematika. Jurnal Eksakta, 2(1), 34-40.

Anggraini, R. (2016). The Effectiveness of Using Chunking Strategy to Improve Students'reading Comprehension at The Second Year of SMP Negeri 2 Barombong. ETERNAL (English, Teaching, Learning, and Research Journal), 1(2), 299-312.

Arryawan, E. (2011). Matematika Yin Yang (Jurus Hitung Sakti Dari Barat dan Timur). Jakarta: PT Elex Media Komputindo.

Blume, A. (2011). Maya concepts of zero. Proceedings of the American Philosophical Society, 155(1), 51-88.

Diputra, G. N. O., \& Sudiarta, I. W. (2018). Penerapan Matematika Veda dalam Operasi Hitung. Suluh Pendidikan, 16(1), 21-30.

Fowler, D., \& Robson, E. (1998). Square root approximations in Old Babylonian mathematics: YBC 7289 in context. Historia Mathematica, 25(4), 366-378.

Fuadi, R., Johar, R., \& Munzir, S. (2016). Peningkatkan kemampuan pemahaman dan penalaran matematis melalui pendekatan kontekstual. Jurnal Didaktik Matematika, 3(1), 47-54.

Gazali, R. Y. (2016). Pembelajaran matematika yang bermakna. Math Didactic: Jurnal Pendidikan Matematika, 2(3), 181-190.

Graciella, M., \& Suwangsih, E. (2016). Penerapan pendekatan matematika realistik untuk meningkatkan kemampuan representasi matematis siswa. Metodik Didaktik: Jurnal Pendidikan Ke-SD-An, 10(2), 27-36.

Hasratuddin. (2018). Membangun Karakter Melalui Pembelajaran Matematika. Jurnal Pendidikan Matematika PARADIKMA, 6(2), 130-141.

Helma, H. (2011). Suatu Analisis Tentang Kebenaran Prinsip Kerja pada Beberapa Sutra dalam Vedic Mathematics. EKSAKTA, 1(1).

Kamarullah, K. (2017). Pendidikan matematika di sekolah kita. Al Khawarizmi: Jurnal Pendidikan Dan Pembelajaran Matematika, 1(1), 21-32.

Lado, H., Muhsetyo, G., \& Sisworo, S. (2016). Penggunaan Media Bungkus Rokok untuk Memahamkan Konsep Barisan dan Deret Melalui Pendekatan RME. Jurnal Pembelajaran Matematika, 3(1), 1-9.

Nasaruddin, N. (2015). Media Dan Alat Peraga Dalam Pembelajaran Matematika. Al-Khwarizmi: Jurnal Pendidikan Matematika Dan Ilmu Pengetahuan Alam, 3(2), 21-30.

Novitasari, D. (2016). Pengaruh penggunaan multimedia interaktif terhadap kemampuan pemahaman konsep matematis siswa. FIBONACCI: Jurnal Pendidikan Matematika Dan Matematika, 2(2), 8-18.

Pardimin, P., \& Widodo, S. A. (2016). Increasing Skills of Student in Junior High School to Problem Solving in Geometry with Guided. Journal of Education and

Alifmatika: Jurnal Pendidikan dan Pembelajaran Matematika, Desember 2020, Vol. 2, No. 2 
Learning, 10(4), 390-395.

Siagian, M. D. (2017). Pembelajaran Matematika Dalam Persfektif Konstruktivisme. NIZHAMIYAH (Jurnal Pendidikan Islam Dan Teknologi Pendidikan), 7(2), 6173.

Sugiyono, S. (2017). Metode Penelitian Bisnis: Pendekatan Kuantitatif, Kualitatif, Kombinasi, dan R\&D. Penerbit CV. Alfabeta: Bandung.

Suharsimi, A. (2006). Prosedur penelitian suatu pendekatan praktik. Jakarta: Rineka Cipta.

TheSchoolRun. (2020). How to do division by chunking. Retrieved from TheSchoolRun website: https://www.theschoolrun.com/what-is-chunking

Thiemann, R. (2013). Computing Square Roots using the Babylonian Method. Archive of Formal Proofs. Http://Afp. Sf. Net/Entries/Sqrt_Babylonian. Shtml.

Vilianti, Y., Pratama, F., \& Mampouw, H. (2018). Description of the ability of social arithedical stories by study problems by students VIII SMP reviewed from the polya stage. International Journal of Active Learning, 3(1), 23-32. 